\title{
Examining How Auditing Text Books Cover the AICPA's Conceptual Frameworks for Ethics
}

\author{
Martin A. Leibowitz ${ }^{1}$, Alan Reinstein ${ }^{2}$ \\ ${ }^{1}$ Joseph Kerzner Chair in Accounting, Assistant Professor,Sy Syms School of Business, Yeshiva University, USA \\ ${ }^{2}$ George R. Husband Professor of Accounting, School of Business Administration, Wayne State University, USA \\ Correspondence: Martin A. Leibowitz, Sy Syms School of Business, Yeshiva University, 500 West 185th Street, New \\ York, USA
}

Received: August 4, 2014

Accepted: October 1, 2014

Available online: October 9, 2014

doi:10.11114/aef.v1i2.549

URL: http://dx.doi.org/10.11114/aef.v1i2.549

\begin{abstract}
The AICPA's Codification of the Code of Professional Conduct (the Revised Code), issued in June 2014, features two "principle-based" conceptual frameworks that employ a "threats and safeguards" approach to CPAs' ethical dilemmas. These 2014 conceptual frameworks reprise concepts and terminology from similar AICPA 2006 and 2008 conceptual frameworks. This article discusses the heightened relevance of principle-based conceptual frameworks and examines how eight major auditing textbooks, all written since the 2006 and 2008 frameworks, cover how contemporary principles-based professional ethics supplement and enhance traditional "rules-based" ethics. The results show that few of the eight examined auditing textbooks cover adequately or at all the Code of Professional Conduct's conceptual frameworks. An appendix presents materials to help auditing professors augment their classroom coverage and to help auditing textbook authors strengthen their future textbook editions.
\end{abstract}

Keywords: Code of Professional Conduct, conceptual framework, principle-based, rule-based, independence framework, threats and safeguards

\section{Introduction}

On June 1, 2014, the AICPA issued a Codification of the Code of Professional Conduct (Revised Code), incorporating and superseding the five components of its prior Code of Professional Conduct (Code): Principles of Professional Conduct (Principles), Rules of Conduct (Rules), Conceptual Framework for Independence (Independence Framework, 2006), Interpretations of Rules of Conduct (Interpretations), and Rulings of the Professional Ethics Executive Committee (Rulings). The Revised Code also incorporates and supersedes the AICPA's Guide for Complying with Rules $102-105$ (Guide, 2008) a conceptual framework designed to help CPAs resolve ethical issues not explicitly covered in the other five components.

The Revised Code (AICPA 2014) features two "principles-based" conceptual frameworks by placing one framework at the outset of Part 1 (Paragraph 1.000.010) for AICPA members in public practice and Part 2 (Paragraph 2.000.010) for members in business. Both frameworks reprise "threats and safeguards" concepts and terminology from the now superseded Independence Framework (2006) and Guide (2008).The AICPA's 2006, 2008, and 2014 "principle-based" conceptual frameworks diverge from long-established "rules-based" approaches, and appear to reflect the AICPA's contemporary mindset and focus of attention.

This article examines (1) the increasing significance of principle-based frameworks in business ethics and other disciplines and (2) eight auditing textbooks' coverage of the 2006 Framework and 2008 Guide, to infer textbook authors' appreciation for the heightened relevance of principle-based conceptual frameworks.

\section{Importance of Conceptual Frameworks}

\subsection{The Trend toward Conceptual Frameworks}

The relevant literature has increasingly called for CPAs and other professionals to rely on conceptual frameworks to provide theoretical and efficient bases to grasp underlying and related concepts. For example, Elliott and Jacobson (1998) advocated for an AICPA conceptual framework for auditor independence, which, in turn, would strengthen the efficiency of the world-wide capital markets. Satava et al. (2006) suggests that a conceptual framework consisting of 
ethical perspectives such as utilitarian benefits, personal virtues and economic efficiency would help prevent future Enron- and Andersen-type audit failures. Moreover, Vidaver-Cohen (1998), Takala and Urpilainen (1999), Sorensen (2002), and Nitsch et al. (2005) state that adopting such frameworks could improve the worldwide ethical and business environment.

The Financial Accounting Standards Board's Conceptual Framework for Financial Reporting (FASB 2010) provides theoretical footing for key financial statement elements, such as approaches to measure and record assets, liabilities, and income. In 2010, the International Accounting Standards Board (IASB) and FASB completed the first phase of a joint project to develop a conceptual framework to harmonize International Financial Reporting Standards and US Generally Accepted Accounting Principles. The IASB and FASB state that their conceptual framework seeks "to create a sound foundation for future accounting standards that are principles-based, internally consistent and internationally converged" (IASB and FASB 2010).

\subsection{The Code's Two Conceptual Frameworks}

The AICPA's Professional Ethics Executive Committee (PEEC) issued the Conceptual Framework for AICPA Independence Standards (the Independence Framework) (AICPA, Professional Standards, vol. 2, ET sec 100.01, 2006), and a Guide for Complying with Rules 102- 505 (the Guide, 2008b).The former framework provides authoritative guidance that AICPA members should use when analyzing independence matters that Code Rule 101 and its Interpretations and Rulings do not explicitly address. The latter framework provides "nonauthoritative" guidance that members are encouraged, but not required, to use when making decisions regarding Code Rules 102 to 505 that the Code and its Interpretations and Rulings do not explicitly address.

Leibowitz and Reinstein (2009) provide examples of applying the Guide's conceptual framework for U.S. practitioners, and Allen (2010) relates the Guide to the International Federation of Accountant's International Ethics Standards Board for Accountants [IESBA] Code of Ethics for Professional Accountants [IESBA Code]. The AICPA Code requires members to consider potential threats to their independence (i.e., risks arising from self-review, advocacy, adverse interest, familiarity, undue influence, and self-interest) and to apply safeguards, if necessary, to bring such potential threats to acceptable levels (e.g., where a reasonable and informed third party, after assessing all specific facts and circumstances, would conclude that the member complied with [i.e., did not compromise] AICPA Standards). Moreover, the IESBA Code parallels the AICPA Code, but asks members to consider related "public interest" factors, such as whether the related securities are publically traded or whether statutes require compliance with independence standards.

\section{Objectives and Methods}

The AICPA's emerging "principles-based" mindset and focus suggests that current auditing textbooks should cover the recently issued principles-based Independence Framework (2006) and Guide (2008). To examine this assumption, we perused the seven existing standard auditing textbooks, plus the primary forensic accounting textbook, which discusses many CPA ethical concepts, and observed the extent of their coverage of these principles-based frameworks.

\section{Results}

\subsection{Overall Results}

Exhibit 1 summarizes textbook coverage of the 2006 Conceptual Framework for AICPA Independence Standards and the 2008 Guide for Complying with Rules 102-505. The discussion of this Exhibit and the conclusions appear in sections 4.2 and 4.3 .

\subsection{Conceptual Framework for AICPA Independence Standards}

Six of the eight textbooks refer to the Independence Framework but only four further explain its innovative threats and safeguards mechanisms. For example, Whittington and Pany $(2014,74)$ explain that "CPAs should evaluate whether a particular threat would lead a reasonable person, aware of all the relevant facts, to conclude that an unacceptable risk of nonindependence exists. " They present the seven categories of threats (self-review, advocacy, adverse interest, familiarity, undue influence, financial self-interest, and management participation). Louwers et al (2013) explains use of the Independence Framework as a "three-step risk-based approach that involves (1) identifying and evaluating threats to independence, (2) determining whether safeguards eliminate or sufficiently mitigate the identified threats, and (3) ascertaining whether independence is impaired. "Moreover, only three textbooks provide examples of independence threats and safeguards.

Since independence is the cornerstone and sine qua non for all assurance services, weak textbook coverage of the Independence Framework is a significant deficiency. 
Exhibit 1. Textbook coverage of key parts of the AICPA Code of Professional Conduct

\begin{tabular}{|c|c|c|c|c|c|c|}
\hline \multirow[b]{2}{*}{ Textbook } & \multicolumn{3}{|c|}{$\begin{array}{l}2006 \text { Conceptual Framework for } \\
\text { AICPA Independence Standards }\end{array}$} & \multicolumn{3}{|c|}{$\begin{array}{c}2008 \text { Guide for Complying } \\
\text { with Rules } 102-505\end{array}$} \\
\hline & $\begin{array}{c}\text { Refers } \\
\text { to the } \\
\text { Framework }\end{array}$ & $\begin{array}{l}\text { Explains the } \\
\text { Framework's } \\
\text { threats and } \\
\text { safeguards }\end{array}$ & $\begin{array}{l}\text { Provides } \\
\text { examples }\end{array}$ & $\begin{array}{l}\text { Refers } \\
\text { to the } \\
\text { Guide }\end{array}$ & $\begin{array}{l}\text { Explains the } \\
\text { Guide's threats } \\
\text { and safeguards }\end{array}$ & $\begin{array}{l}\text { Provides } \\
\text { examples }\end{array}$ \\
\hline Arens et al (2014) & Yes & No & No & Yes & No & No \\
\hline Hooks (2011) & Yes & No & No & No & No & No \\
\hline Johnstone et al (2014) & Yes & Yes & Yes & No & No & No \\
\hline $\begin{array}{l}\text { Kranacher et al (2011) } \\
\text { [Forensic Accounting } \\
\text { Textbook] }\end{array}$ & No & No & No & No & No & No \\
\hline Louwers et al (2013) & Yes & Yes & Partial & No & No & No \\
\hline Messier et al (2012) & Yes & Yes & No & No & No & No \\
\hline Stuart (2012) & No & No & No & No & No & No \\
\hline $\begin{array}{l}\text { Whittington and } \\
\text { Pany (2014) }\end{array}$ & Yes & Yes & Yes & No & No & No \\
\hline
\end{tabular}

\subsection{Guide for Complying with Rules $102-505$}

The Code cannot address every potential ethical threat. To assist all CPAs, including those in business and government, the PEEC in 2008 issued a Guide for Complying with Rules 102 - 505 that provides non-authoritative guidance when CPAs face threats to ethical ideals of the "Six Underlying Principles" (responsibilities, protecting the public interest, integrity, objectivity and independence, due care, and scope of services) not addressed in the Code, Interpretations, or Ethical Rulings. The Guide covers all facets of ethics, except independence which is addressed in the Independence Framework.

Of the eight textbooks, only Arens et al (2014) refers to the Guide. Their coverage is in a sidebar that aptly states, "The guide contains a risk-based framework that outlines categories of potential threats to compliance with the [underlying] principles and includes suggested safeguards to prevent noncompliance." Their one paragraph concludes with advice that, "...members should refer to the framework when making decisions on ethical matters not explicitly addressed in the code." They neither define nor explain "threats and safeguards" nor provide examples. The other seven textbooks are silent about the Guide.

\section{Recommendations}

Textbook authors should explain that AICPA members should use the new conceptual frameworks (Independence Framework and the Guide) when no specific guidance exists within the Code's Rules, Interpretations or Rulings. The AICPA's Professional Ethics Executive Committee explains that their frameworks' "risk-based approach" involves:

[identifying, evaluating and addressing] threats to meeting the objectives of the fundamental principles when making decisions on ethical matters that are not explicitly addressed by the Code... If an identified threat is ... more than trivial and inconsequential, the member should apply safeguards to eliminate the threat or reduce it to an acceptable level. . . If a threat cannot be sufficiently mitigated through the application of safeguards..., the member should decline or discontinue the specific professional service... The member also should consider whether it is appropriate to resign from the client or [for members in industry, government, or education] the employing organization (AICPA 2008a)

Significant provisions of the frameworks that textbook authors may want to include in future textbook editions appear in the appendix to this examination.

\section{Summary}

Textbooks should fully prepare students for classroom engagement regarding the structure and details of auditor independence and ethics pronouncements. This should include using conceptual frameworks to help solve ethical dilemmas not explicitly addressed in the Code's Rules, Interpretations, or Rulings. Our examination shows that most auditing textbook authors currently fail to include critical information regarding the conceptual frameworks, which 
hopefully they will add in their next editions. Meanwhile, auditing faculty members can review the contents of Exhibit 1 to assess their textbook's coverage of these matters or even to decide which textbook to adopt. They could also supplement their current auditing ethics presentations with information found at AICPA websites and other relevant information, as suggested in the appendix to this examination. The appendix also summarizes significant provisions of the risk-based approach found in the AICPA's conceptual frameworks and proposes homework exercises.

\section{Appendix}

Supplemental sources, summary of significant provisions of the AICPA's ethics conceptual frameworks, and proposed student exercises

\subsection{Supplemental Sources}

Auditing textbook authors should briefly explain conceptual framework theory and evolution, in general, [see Elliott and Jacobson (1998), Satava et al. (2006), Vidaver-Cohen (1998), Takala and Urpilainen (1999), Sorensen (2002), or Nitsch et al. (2005)] and then present ethical ideals from the Revised Code's six "Principles of Professional Conduct": responsibilities principle, public interest principle, integrity principle, objectivity and independence principle, due care principle, and scope and nature of services principle (AICPA 2014, Paragraphs 0.300.020 to 0.300.070) [see Leibowitz and Reinstein (2014)]. The six "Principles of Professional Conduct" provide context for presenting the Revised Code's seven threats to meeting ethical ideals.

\subsection{Summary of Significant Provisions of the AICPA's Ethics Conceptual Frameworks}

1) Adverse interest threat - "The threat that a member will not act with objectivity because the member's interests are opposed to the client's interests" (AICPA 2014, Paragraphs 1.000.010.10).

2) Advocacy threat — "The threat that a member will promote a client's interests or position to the point that his or her objectivity of independence is compromised" (AICPA 2014, Paragraphs 1.000.010.11).

3) Familiarity threat - The threat that, due to a long or close relationship with a client, a member will become too sympathetic to the client's interests or two accepting of the client's work or product. (AICPA 2014, Paragraphs 1.000.010.12).

4) Management participation threat - "The threat that a member will take on the role of client management or otherwise assume management responsibilities, such may occur during an engagement to provide no attest services" (AICPA 2014, Paragraphs 1.000.010.13)

5) Self-interest threat - "The threat that a member could benefit, financially or otherwise, from an interest in, or relationship with, a client or persons associated with the client (AICPA 2014, Paragraphs 1.000.010.14).

6) Self-review threat - "The threat that a member will not appropriately evaluate the results of a previous judgment made or service performed or supervised by the member or an individual in the member's firm and that the member will rely on that service in forming a judgment as part of another service (AICPA 2014, Paragraphs 1.000.010.15).

7) Undue influence threat — "The threat that a member will subordinate his or her judgment to an individual associated with a client or any relevant third party due to that individual's reputation or expertise, aggressive or dominant personality, or attempts to coerce or exercise excessive influence over the member (AICPA 2014, Paragraphs 1.000.010.16).

Similar threats are applicable to members in business (AICPA 2014, 2.000.010.09 to 2.000.010.14), except "management participation threat," which applies only to members in public practice.

Authors should define and link "safeguards" to threats, explaining that safeguards are "actions or other measures that may eliminate a threat or reduce a threat to an acceptable level" (AICPA 2014, Paragraphs 1.000.010.05). The Revised Code provides ample, clear illustrations of threats and safeguards that can be incorporated into textbooks and classrooms.

\subsection{Student Exercises}

Professors can ask students to clarify the threats and safeguards approach by devising their own creative examples of threats and remedial safeguards, such as found in Leibowitz and Reinstein (2009), Johnstone et al (2014), Whittington and Pany (2014):

- A policy of periodically rotating senior members on an attest engagement reduces familiarity threats.

- A report that monitors reliance on revenue from a firm's two or three largest clients increases the likelihood of identifying and managing undue influence and financial self-interest threats.

- An anonymous complaint-reporting system that encourages employees, clients and the public to report unethical 
behavior increases the likelihood of a member identifying and changing suspect unethical behavior, without fear of retribution.

- A client's corporate governance structure that provides appropriate oversight of the firm's services decreases the likelihood of management participation threats.

- A private-company's policy of consulting with outside CPAs in applying new accounting standards can mitigate both advocacy and familiarity threats to its in-house CPAs.

More challenging classroom exercises could present threat-scenarios as case studies (beyond the scope of this article) and ask students to identify the threats' types and levels of significance. For each threat-scenario, the case could ask students to devise effective safeguards or to state that the CPA's best response is to withdraw from the task or client. Such exercises should help students develop critical thinking skills and familiarity with primary sources by citing relevant paragraphs in the Revised Code (AICPA 2014).

\section{Acknowledgements}

We appreciate the comments from Mohammad J. Abdolmohammadi [Bentley University], Brian Green [University of Michigan-Dearborn], Jim Rebele [Robert Morris University], Thomas Roach, M.S. Student, Wayne State University, and Stefanie Tate [University of Massachusetts-Lowell] on earlier drafts of this paper.

\section{References}

Allen, C. (2010). Comparing The Ethics Codes: AICPA and IFAC, Journal of Accountancy, 210(4), 24-32.

AICPA. (2006). Conceptual Framework for AICPA Independence Standards http://www.aicpa.org/Research/Standards/CodeofConduct/Pages/et_100.aspx\#et_100_.01

(2008a). Professional Ethics Executive Committee [PEEC], Open Meeting Agenda, January 31- February 1, 2008, NewOrleans, LA. http://www.aicpa.org/InterestAreas/ProfessionalEthics/Community/MeetingMinutesandAgendas/DownloadableDo cum ents/2008JanuaryPEECAgenda.pdf

. (2008b). Guide for Complying with Rules 102-505.

http://www.aicpa.org/InterestAreas/ProfessionalEthics/Resources/Tools/DownloadableDocuments/Guide_for_Co mplying_with_Rules_102_Through_505_11_10_08_Edited.pdf Accessed on August 12, 2013

. (2010). Composition, Applicability, and Compliance: Code of Professional Conduct. http://www.aicpa.org/about/code/comp.htm. Accessed on September 8, 2013.

. (2014). AICPA Code of Professional Conduct.

http://www.aicpa.org/Research/Standards/CodeofConduct/DownloadableDocuments/2014December15ContentAso f2014May15CodeofConduct.pdf. Accessed on July 22, 2014

Arens, A., R. Elder, \& M. Beasley. (2014). Auditing and Assurance Services: An Integrated Approach, 15th ed. Prentice Hall

Elliott, R. K., \& P. D. Jacobson. (1998). Audit Independence Concepts, The CPA Journal, 68(12) 30-37

FASB. (2010). Statement of Financial Accounting Concepts No. 8: Conceptual Framework for Financial Reporting. http://www.fasb.org/cs/BlobServer?blobkey=id\&blobnocache=true\&blobwhere=1175822892635\&blobheader=app lication\%2Fpdf\&blobcol=urldata\&blobtable=MungoBlobs Accessed on August 20, 2013

Hooks, K. (2011). Auditing and Assurance Services: Understanding the Integrated Audit. Wiley

IASB and FASB. (2010). News Release, September 28, 2010, http://www.fasb.org/cs/ContentServer?pagename=FASB/FASBContent_C/NewsPage\&cid=1176157497474, accessed on August 12, 2013.

Johnstone, K., Gramling, A., \& Rittenburg, L. (2014). Auditing: A Risk-Based Approach to Conducting a Quality Audit, $9^{\text {th }} e d$. Thomson South-Western

Kranacher, M., \& R. Riley, J. (2011). Wells Forensic Accounting Wiley.

Leibowitz, M. A., \& Alan, R. (2009). Help for Solving CPAs "Ethical Dilemmas," Journal of Accountancy, 207(4), 30-34.

. (2014). Ethics Mindsets, New and Old, Journal of Contemporary Business Issues, 19(1) 11-20

Louwers, T., Ramsay, R., Sinason, D., Strawser, J., \& Thibodeau, J. (2013). Auditing and Assurance Services, $5^{\text {th }}$ ed. McGraw-Hill Irwin. 
Mastracchio Jr., N. J., Lively, H. M. \& Carlson, E. T. (2011). Should A Master's Degree Be Required For CPA Licensure? The CPA Journal, 81(11), 9-11.

Messier, W. S., \& Prawitt, G. D. (2012). Auditing and Assurance Services: A Systematic Approach, $8^{\text {th }}$ ed. McGraw-Hill Irwin.

Taylor, M. J., \& Thomas, C. W. (2011). Clarified Auditing Standards: The Quiet Revolution, Journal of Accountancy, 211(6), 24-28.

Nitsch, D., Baetz, M., \& J. C. Hughes. (2005). Why Code Of Conduct Violations Go Unreported: A Conceptual Framework To Guide Interventions And Future Research, Journal of Business Ethics, 57(4), 327-341. http://dx.doi.org/10.1007/s10551-004-8203-6

Satava, D., Caldwell, C., \& Richards, L. (2006). Ethics and the Auditing Culture: Rethinking the Foundation of Accounting Auditing, Journal of Business Ethics, 64 (3): 271-284. http://dx.doi.org/10.1007/s10551-005-0556-y

Sorensen, A. (2002) Value, Business and Globalisation - Sketching a Critical Conceptual Framework, Journal of Business Ethics, 39(1-2), 161-167. http://dx.doi.org/10.1023/A:1016308807142

Stuart, I. (2012). Auditing and Assurance Services: An Applied Approach McGraw-Hill Irwin

Takala, T., \& Urpilainen, J. (1999). Managerial Work and Lying: A Conceptual Framework and an Explorative Case Study, Journal of Business Ethics, 20(3), 181-195.

Vidaver-Cohen, D. (1998) Moral Climate in Business Firms: A Conceptual Framework for Analysis and Change, Journal of Business Ethics, 17 (1), 211-1, 226.

Whittington, O., Pany, K. (2014). Principles of Auditing and Assurance Services, $19^{\text {th }}$ ed.

\section{$(c)$ EY}

This work is licensed under a Creative Commons Attribution 3.0 License. 